\title{
Port Performance of the Malay Peninsula: Focusing on the Malacca Strait*
}

\author{
Yau Weng Loh**, Tae Seung Kim**
}

\begin{abstract}
In the single-cargo market, the ordinary market share analysis method has been the representative tool for revealed competitiveness analysis. This paper develops and employs an applied market share index called the additive market share (AMS). Data are collected from 8 major ports for the 2001-2013 period. In comparison to the results of an ordinary market share analysis, there has been some fluctuation of the role of the Port of Singapore as the regional hub port though it still maintain its position. There are substitutable relationships between Singapore and the Malaysian ports in Malacca Strait. In Malacca Strait, Port Klang still leads the market in spite of the construction of PTP.
\end{abstract}

Key Words: Port Competitiveness, Additive Market Share, Port Cluster, Malacca Strait

JEL codes: L16, L91, O53, R12

* This paper is revised based on the thesis of Loh (2011) and was supported by the research grant of Inha University.

** SCM Executive, DKSH Malaysia Sdn Bhd, B-11-01, The Ascent, Paradigm, No.1, Jalan SS7/26A, Kelana Jaya, 47301 Petaling Jaya, Selangor Darul Ehsan, Malaysia. E-mail: casperloh@yahoo.com

*** Corresponding Author. Associate Professor, Asia Pacific School of Logistics, Inha University, 100 Inha-ro, Nam-gu, Incheon, 402-751, Korea. E-mail: todang@inha.ac.kr 


\section{Introduction}

Around ninety per cent of world trade is carried by shipping industry (Talley, 2004), thus maritime transport plays a vital role in world trade. Malaysia, as a maritime nation, is following this trend also, in which more than ninety per cent of Malaysia trade is transported via sea (Why Malaysia, 2010). Port Klang and Port of Tanjung Pelepas (PTP) are listed among the top twenty largest container ports in world ranking. PTP which has just commenced its operations about ten years ago has been recognized as one of the world top twenty largest container ports starting from 2003. This trend had induced the importance to measure the performance of Malaysian seaports.

However, the performance of a port is usually judged only by the volume or the growth rate of container or cargo throughput, and further assessment of the performance is rarely conducted. If a port functions as the economic gateway of a state, a high percentage of trade flows in and out the state via that port. For state encompasses more than one port, one or more of those ports might be the gateway of that particular state, or none of them works as the gateway, but port from other state takes the post as the gateway. There could be also a situation where the gateway is not a port, and trade is dealt via other transport modes. This situation is the same for the gateway of a nation, too.

There is a need to assess a port whether it is the potential economic gateway for the state where it is located and for the nation. Therefore, the main purpose of this paper is to investigate the competitiveness of Malaysian ports, in terms of growth potential, based on the performance of the ports' throughput. Upon revealing the competitiveness indices, the next purpose is to identify the regional (state) and national gateway port(s) and the interrelation among ports. Especially the substitutability or complementarity among ports are evaluated based on the performance indices.

The rest of this paper is organized as follows: Section 2 provides a review of previous research on port competitiveness and performance. Section 3 discusses the methodology, the ordinary market share analysis, the revealed competitiveness advantage (RCA), and the additive market share (AMS). Brief introduction on the market and the description of data are provided in Section 4. Section 5 presents the empirical results and their policy implications, and Section 5 concludes with a summary and some suggestions for future research. 


\section{Literature Review}

Talley (2007) raises three issues for the evaluation scope of port competitiveness: evaluation over time (a single-port approach), evaluation relative to other ports (a multi-port approach), and evaluation from an engineering or economic perspective. A single-port approach compares actual performance to optimum performance and traces them over time. Here the major performance indicators include throughput, employment, value added, and the investment level, which are precisely investigated and suggested for improvement in de Langen et al. (2007).

A multi-port approach compares performance indicators used in a single-port approach between ports in a competitive environment. However, this method is seriously limited in that it may mislead results as a result of ports operating in different economic, social, and fiscal environments (Talley, 2007). Therefore, multi-port comparison methods have evolved into the data envelopment analysis (DEA) technique for a comparison of ports' relative efficiency and the analytical hierarchy process (AHP) technique for giving weight to port choice criteria for shippers and liners.

Pallis et al. (2010) and Pallis et al. (2011) provide a collective literature review on ports by considering a total of 395 papers published in major journals during the 1997-2008 period and classifying them based on research communities, subfields, citation frequency, and sub-periods. According to their statistics, the fields of research, particularly during the 2002-2006 period, have concentrated on port (or terminal) competitiveness. Here the main research themes include port efficiency and choice, as explained earlier. This implies an increase in port competition since the 2000s, and the major sources of competitiveness include the promotion of efficiency and the attraction of shippers and liners.

However, despite the importance of port competitiveness, few studies have developed the methods of evaluation for them during this period. Several ordinary performance indicators such as throughput and the growth rate have been used as indices of ports' revealed competitiveness. It is just after the collective works by Pallis et al. (2011) when researchers have focused on developing new indicators of revealed competitiveness.

Low et al. (2009) use the port connectivity index and the port cooperation index to assess the hub status of major Asian ports. One serious limitation of their study is that they use data from anonymous liners, which means that the method may not be applicable to other studies with no confidential data from liners. Another approach is the network analysis method in Notteboom (2009), who investigates the number of calls of liners at major ports in Northern Europe and analyzes the complementarity and substitutability of those ports. However, his research is limited in that competitiveness cannot be compared 
across all ports considered. Tsamourgelis et al. (2013) introduce the generalized method of moments (GMM) to evaluate the relationship between port throughput and GDP in the hinterland. However, their study does not focus on the competitiveness of a port itself, instead showing the competitiveness of port hinterlands.

For a comparative analysis of ports in the Asia-Pacific region, Liu (2008) uses the DEA method, whereas Yeo et al. (2008), the AHP method. Other methods have been used to estimate the efficiency of ports in a similar region as well. For example, Tongzon et al. (2005) use the stochastic frontier analysis model (SFM). There were some performance evaluations done on Malaysian ports by Culllinane et al. (2005) and Tongzon et al. (2005). However, the principal focus of them was not on Malaysian ports but on ASEAN ports, Asian ports, etc. In addition, the Malaysian ports engaged in the measurement were only Port Klang and Port of Tanjung Pelepas (PTP), and seldom involved other Malaysian ports. Consequently, the results did not reflect Malaysian maritime industry. In year 2007, there was one research conducted by Ng and Lee (2007) utilizing DEA method, which reflected Malaysian ports' performance.

\section{Methodology}

This paper takes a more direct approach to evaluate the competitiveness of ports by using a data set that is easier to collect than those in the literature.

As discussed earlier, previous studies have focused mainly on three fields: the efficiency of ports, port choice criteria of shippers and liners, and the competiveness of networks and hinterlands. However, although these may be potential, stated, or indirect measures of competitiveness, they are not real, revealed, or direct measures of port competitiveness, respectively. In particular, ports in Southeast Asia have made substantial efforts to increase their efficiency, attract major liners and shippers, extend their networks, and develop hinterlands for about a decade. In this regard, there is a need to measure the change of the real and revealed competitiveness of ports in the region during the period.

One of the popular method for evaluating the competitiveness or comparative advantage of an industry in a region is the revealed comparative advantage (RCA) method (Balassa, 1965). The RCA entails an index for measuring the ratio of the product or export volume of a certain industry in a country to that of the same industry in the world. If the index value is greater (less) than 1 in an industry of a country, then that industry is said to have a comparative (dis) advantage in the world trade market. 
A serious limitation in using the RCA to examine port competitiveness is the need for multiple products in multiple regions. If the data set includes only one product or region, then it is condensed into nothing but some share of the product or region in the whole market. The market share is frequently used as a performance indicator of ports either in a single- or multi-port approach. Although it provides meaningful insights into the revealed competitiveness of ports, it cannot be a new indicator.

Given the purpose and scope of this paper, a new method for calculating the market share is proposed based on a single product over a given period, namely the additive market share (AMS), which is measured as follows:

$$
\begin{aligned}
& A M S_{i}=\frac{\frac{P_{t}^{i}-P_{t-1}^{i}}{P_{t}^{i}}}{\frac{\sum_{i=1}^{n}\left(P_{t}^{i}-P_{t-1}^{i}\right)}{\sum_{i=1}^{n} P_{t}^{i}}} \times \frac{P_{t}^{i}}{\sum_{i=1}^{n} P_{t}^{i}}=\frac{\left(P_{t}^{i}-P_{t-1}^{i}\right) \times \sum_{i=1}^{n} P_{t}^{i}}{P_{t}^{i} \times \sum_{i=1}^{n} P_{t}^{i}\left(P_{t}^{i}-P_{t-1}^{i}\right)} \times \frac{P_{t}^{i}}{\sum_{i=1}^{n} P_{t}^{i}}=\frac{\left(P_{t}^{i}-P_{t-1}^{i}\right)}{\sum_{i=1}^{n} P_{t}^{i}\left(P_{t}^{i}-P_{t-1}^{i}\right)} \\
& \sum_{i=1}^{n} A M S_{i}=\sum_{i=1}^{n} \frac{\left(P_{t}^{i}-P_{t-1}^{i}\right)}{\sum_{i=1}^{n}\left(P_{t}^{i}-P_{t-1}^{i}\right)}=\frac{\sum_{i=1}^{n}\left(P_{t}^{i}-P_{t-1}^{i}\right)}{\sum_{i=1}^{n}\left(P_{t}^{i}-P_{t-1}^{i}\right)}=1
\end{aligned}
$$

where $P_{t}^{i}$ is the container volume of port $i$ at time $t$. As can be seen from the formula, the first term on the left-hand side represents the relative growth rate, and the second term, the ordinary market share (OMS). In addition, the AMS is the weighted OMS in which the weight is the relative growth rate calculated by using the Paasche index instead of the ordinary Laspeyres index. The weight is greater (less) than 1 if the growth rate of a port is greater (less) than the market average. Based on this method, the left-hand side of the formula is automatically converted into the right-hand side, and the total AMS is 1. This means that the AMS has the property of both the OMS and the growth rate, and this is its most important characteristic. The advantages of the AMS method over the OMS method can be summarized as follows:

First, a short-term change in competitiveness can be easily detected using the AMS. If a port gains competitiveness within a certain period of time, then the AMS increases faster than the OMS because the AMS is the market share from the increased volume of containers in the market during that period. This means that the short-term change in competitiveness, which may be hidden in the OMS, can be found only by observing changes in the AMS without separately calculating the growth rate. 
Second, the AMS method can show the level of on-the-spot competitiveness for ports, which cannot be done using the OMS method. If a port improves its competitiveness relative to that of other ports, then its AMS ranks higher. However, in the OMS method, any improvement in a port's competitiveness may not appear because it is incorporated in the cumulated path of competitiveness.

Third, changing trends and responses to shocks can be used to more clearly identify the complementarity or substitutability of ports by AMS than OMS. If the AMS moves in the same (different) direction after a shock for two ports, then they are assumed to have a complementary (substitutable) relationship.

\section{Scope of Analysis and Data}

\subsection{Ports Location in Malaysia}

There are generally thirty three ports in Malaysia located at thirteen states in West Malaysia (Peninsula) and East Malaysia (Sabah, Sarawak). Among them, 7 ports are designated as the Federal Ports, and 11 ports, as the State Ports, as of the end of 2013. But 6 out of 7 federal ports are located in West Malaysia and only 1 port, in East Malaysia (Sarawak). Though there are 8 state ports in Sabah, no port is designated as the federal port. Among 6 federal ports in West Malaysia, 4 ports are located along the Malacca Strait, which are Johor, Tanjung Pelepas, Klang, and Penang, from the south to the north.

The largest port in terms of container throughput is Port Klang, followed by PTP, Penang, Johor, etc. In terms of total cargo throughput, Port Klang is still the largest one and PTP, Bintulu, Penang, Johor, etc. There are little differences between the two orders except the position of Bintulu which is the gate port in Sarawak. This means that major ports in the region are those along the Malacca Strait. 


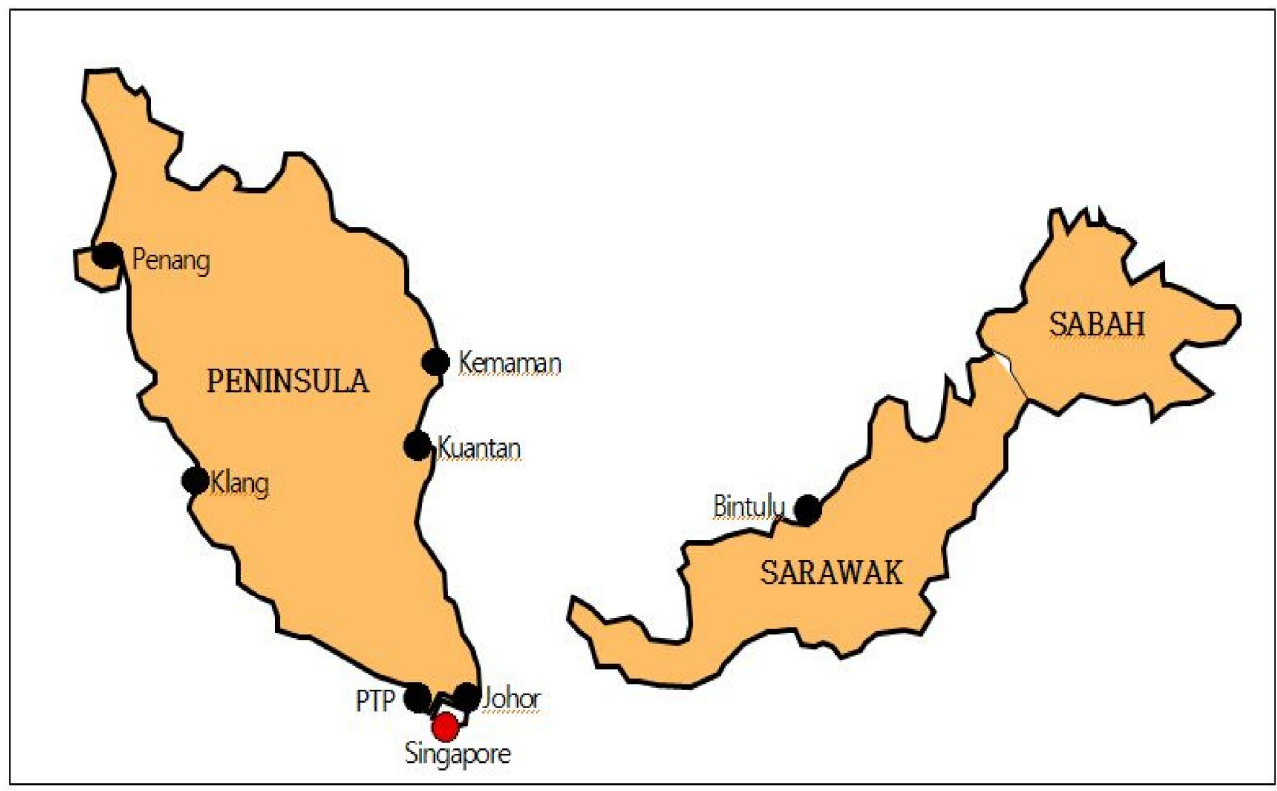

Figure 1.

Major ports in Malaysia and Singapore

Another point to be considered is that the performance of ports in Malaysia cannot be explained without considering the role of the Port of Singapore, which is the largest transshipment hub port in the world. Geographically located just adjacent to the ports in Malaysia, the Port of Singapore have shared its role of transshipment hub with the ports in Malaysia and it also functions as the gateway of international cargo of the Malay Peninsula. Hence, to evaluate the port performances of ports in Malaysia, this paper consider the data of the Port of Singapore as well as those of the ports in Malaysia.

In considering the data of ports in the region, this paper classifies them into 3 zones, which are the ports in Malaysia along the Malacca Strait (Malacca), those in other region (Region), and the Port of Singapore (Singapore). Malacca includes Johor, PTP, Klang and Penang, while Region consider Kemaman, Kuantan, Bintulu, and the state ports in Sabah. The reasons of this classification are as follows;

First, to find out the roles of ports in the region, the relation between Malacca and Singapore is utmost important. Second, the relation between Malacca and Others worth another analysis for the performance evaluation of the ports in Malaysia as a whole. Third, after the analysis among the zones, the role of individual ports in Malacca, especially the relation between Klang and PTP should be analyzed. 


\subsection{Data}

Table 1.

Data and Descriptive Statistics

\begin{tabular}{|c|c|c|c|c|c|c|c|c|}
\hline \multirow{2}{*}{ Year } & \multicolumn{4}{|c|}{ Total throughput (unit: 000 TEU) } & \multicolumn{4}{|c|}{ T/S throughput (unit: 000 TEU) } \\
\hline & Malacca & Singapore & Region & Total & Malacca & Singapore & Region & Total \\
\hline 2001 & $5,002.5$ & $15,571.1$ & 136.7 & $20,710.3$ & - & - & - & - \\
\hline 2002 & $8,519.6$ & $16,940.9$ & 188.3 & $25,648.8$ & - & - & - & - \\
\hline 2003 & $9,596.8$ & $18,410.5$ & 244.4 & $28,251.8$ & $3,168.7$ & $15,059.8$ & 104.1 & $18,332.6$ \\
\hline 2004 & $10,657.3$ & $21,329.1$ & 468.0 & $32,454.4$ & $6,383.3$ & $17,447.2$ & 86.1 & $23,916.5$ \\
\hline 2005 & $11,358.2$ & $23,192.2$ & 475.4 & $35,025.8$ & $7,111.2$ & $18,785.7$ & 85.1 & $25,982.0$ \\
\hline 2006 & $12,714.1$ & $24,792.4$ & 552.7 & $38,059.2$ & $8,141.6$ & $20,205.8$ & 119.0 & $28,466.4$ \\
\hline 2007 & $14,269.6$ & $27,935.5$ & 650.9 & $42,856.0$ & $9,358.9$ & $22,814.9$ & 147.8 & $32,321.7$ \\
\hline 2008 & $15,292.2$ & $29,918.2$ & 709.9 & $45,920.3$ & $10,088.0$ & $24,485.1$ & 144.7 & $34,717.8$ \\
\hline 2009 & $14,948.2$ & $25,866.6$ & 658.5 & $41,473.3$ & $10,060.5$ & $21,210.6$ & 115.0 & $31,386.1$ \\
\hline 2010 & $17,152.8$ & $28,431.1$ & 720.2 & $46,304.1$ & $11,601.6$ & $23,526.7$ & 117.9 & $35,246.2$ \\
\hline 2011 & $18,938.9$ & $29,937.7$ & 704.4 & $49,581.0$ & $13,185.5$ & $24,998.0$ & 91.0 & $38,274.4$ \\
\hline 2012 & $19,462.1$ & $31,649.4$ & 741.8 & $51,853.3$ & $13,532.0$ & $26,664.6$ & 65.2 & $40,261.8$ \\
\hline 2013 & $19,761.7$ & $32,578.7$ & 749.9 & $53,090.3$ & $13,671.1$ & $27,691.9$ & 78.7 & $41,441.7$ \\
\hline Mean & $13,667.2$ & $25,119.5$ & 538.6 & $39,325.3$ & $9,663.8$ & $22,080.9$ & 105.0 & $31,849.8$ \\
\hline s.d. & $4,374.3$ & $5,443.7$ & 211.7 & $9,939.7$ & $3,153.5$ & $3,757.6$ & 25.4 & $6,847.5$ \\
\hline $\mathrm{V}^{*}$ & 32.0 & 21.7 & 39.3 & 25.3 & 32.6 & 17.0 & 24.2 & 21.5 \\
\hline
\end{tabular}

* V: Coefficient of Variation 


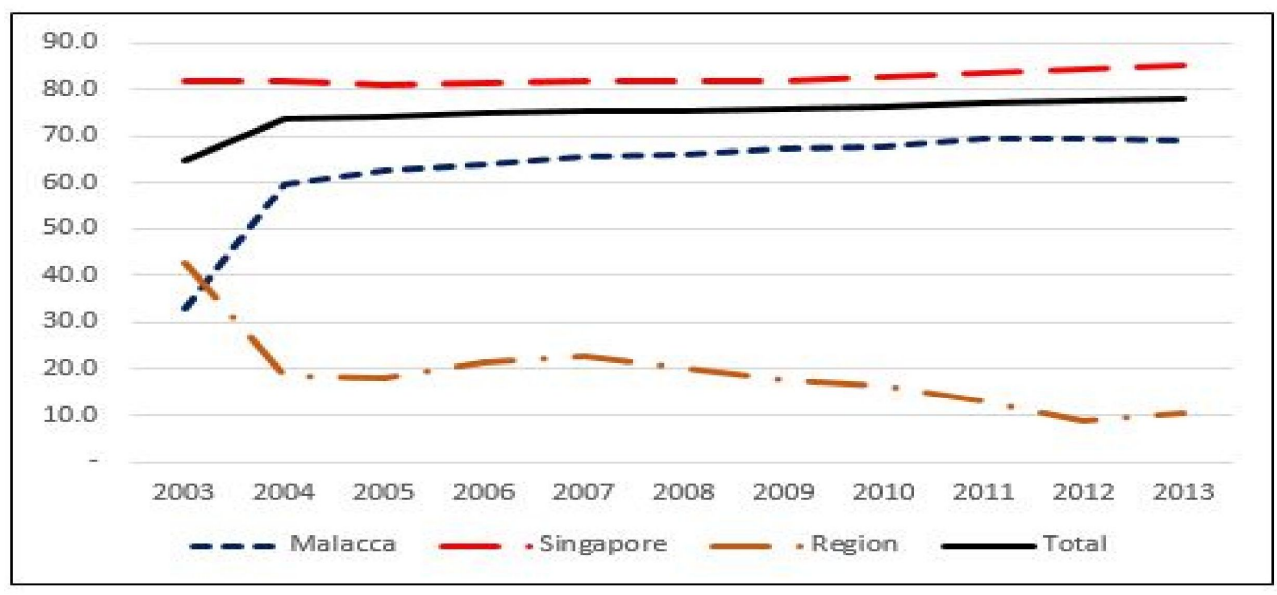

Figure 2.

Transshipment ratio by zones

Data on the annual container-handling volume of major ports in the region for the period of 2001-2013 are collected. We divide the container volumes of each port or zone into the transshipment throughput and the net O-D throughput. By doing this, we can not only analyze overall performance of the ports or zones, but also identify whether the ports have the characteristics of transshipment hub or the gateway ports. Table 1 and Figure 2 show the data and the results of the descriptive analysis.

\section{Analysis Results}

\subsection{OMS Analysis Results}

The OMS and the growth rate are the most popular indicators of port performance either in the single- or multi-port approach in existing researches. The former explains the relative competitiveness of a port at a certain point of time, whereas the latter shows the competitiveness change over time.

As can be seen in Table 1, the container throughput in the region has increased dramatically over the 10 years. Average growth rate is around 7\%, is faster than the world growth rate, 6\%, among which Malacca has recorded the fastest, 8.1\%. Figures 3 and 4 show the OMS and the growth rate of the region by zones. 


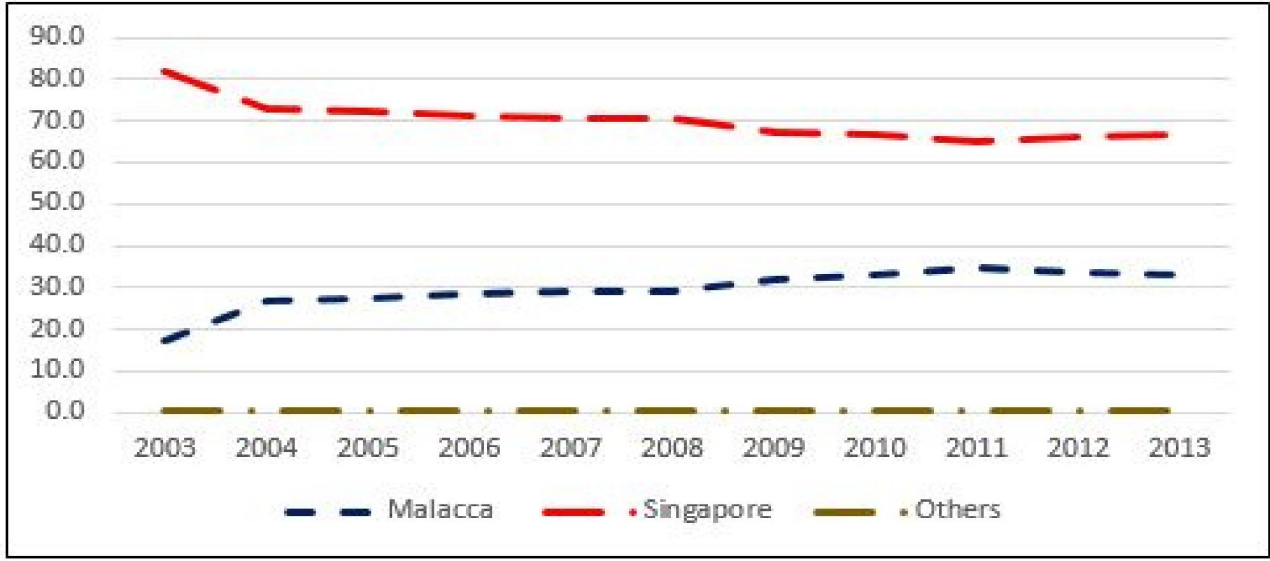

Figure 3.

OMS by zone

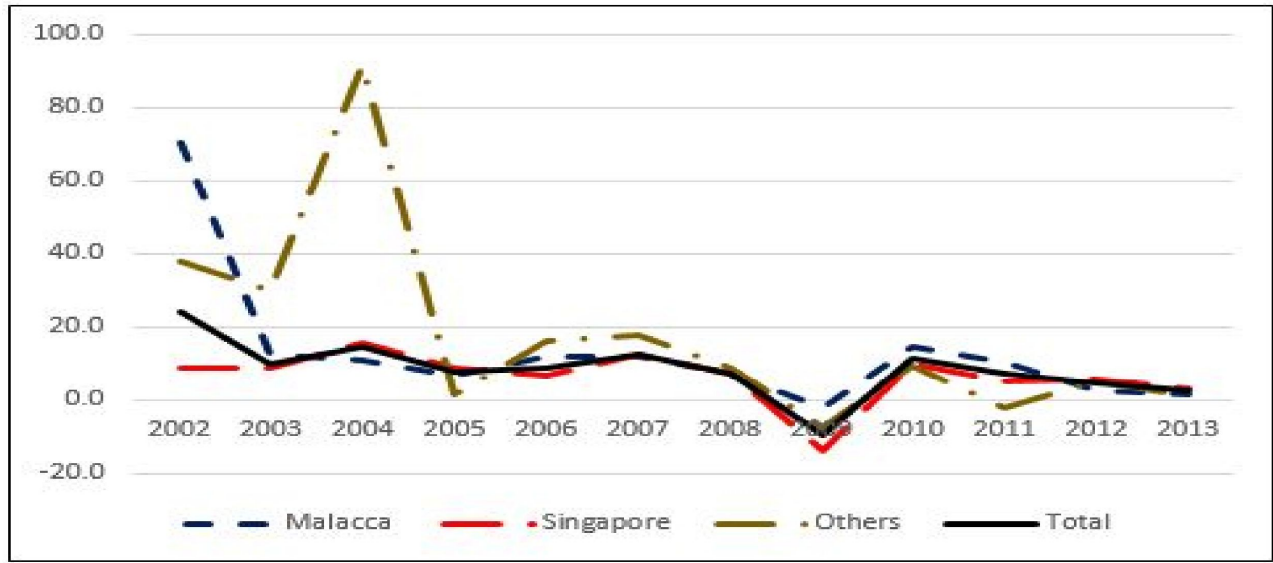

Figure 4.

Growth rates by zone

These two figures provide the following results:

First, despite some weakening, Singapore maintains its competitive superiority throughout the period. Malacca gains its competitiveness gradually, whereas Region is stagnant around $1 \%$ of market share. Second, the growth rate of Region has been fluctuating due to the relative small amount of container throughput share. Third, there are two external shocks during the period, which are 2003-2005 and 2008-2009, potentially affecting the competitiveness of each port, and the overall growth rate in the region shows a downward trend over time. 


\subsection{AMS Analysis Results by Zone}

Figure 5, 6, and 7 show the results of the AMS analysis over past 10 years, based on total container throughput, T/S throughput, and net O-D throughput, respectively.

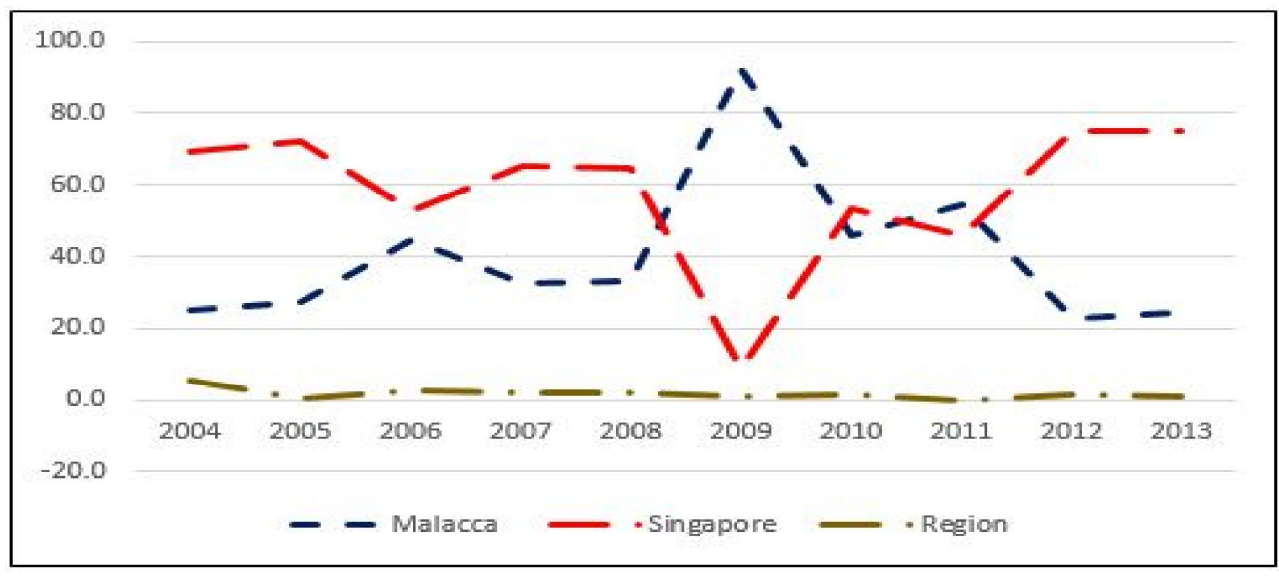

Figure 5.

AMS by zone (Total container throughput)

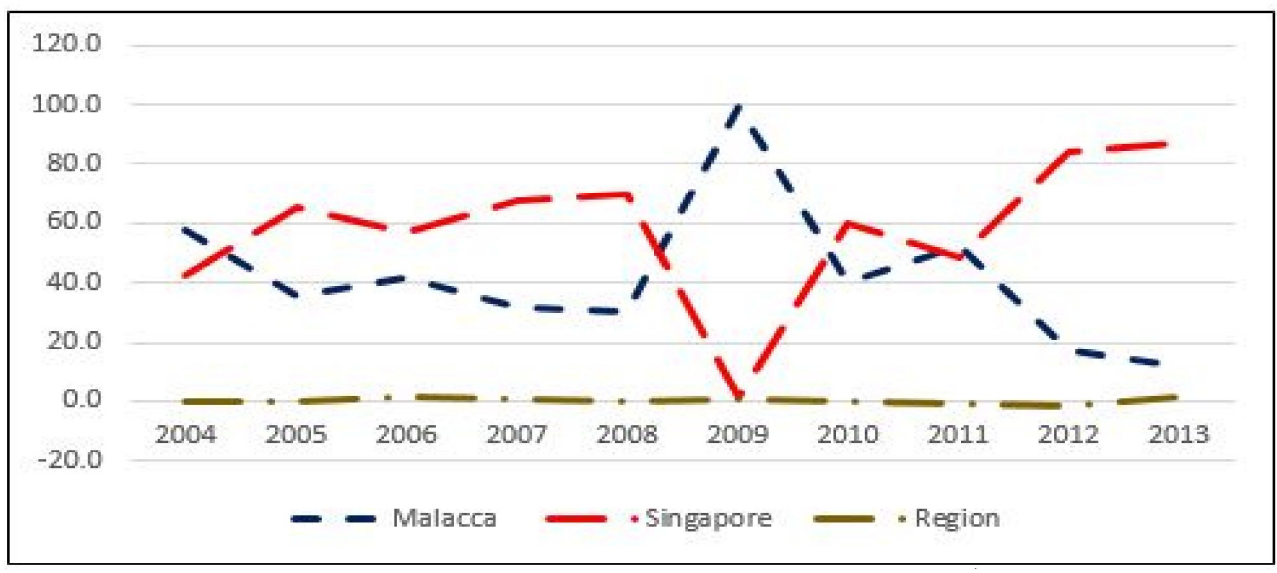

Figure 6.

AMS by zone ( $\mathrm{T} / \mathrm{S}$ container throughput $)^{1)}$

1) The AMS is the market share of the added volume of cargo in the market, and therefore it, by its nature, may have negative values if the total volume of a port decreases, increasing that of others. 


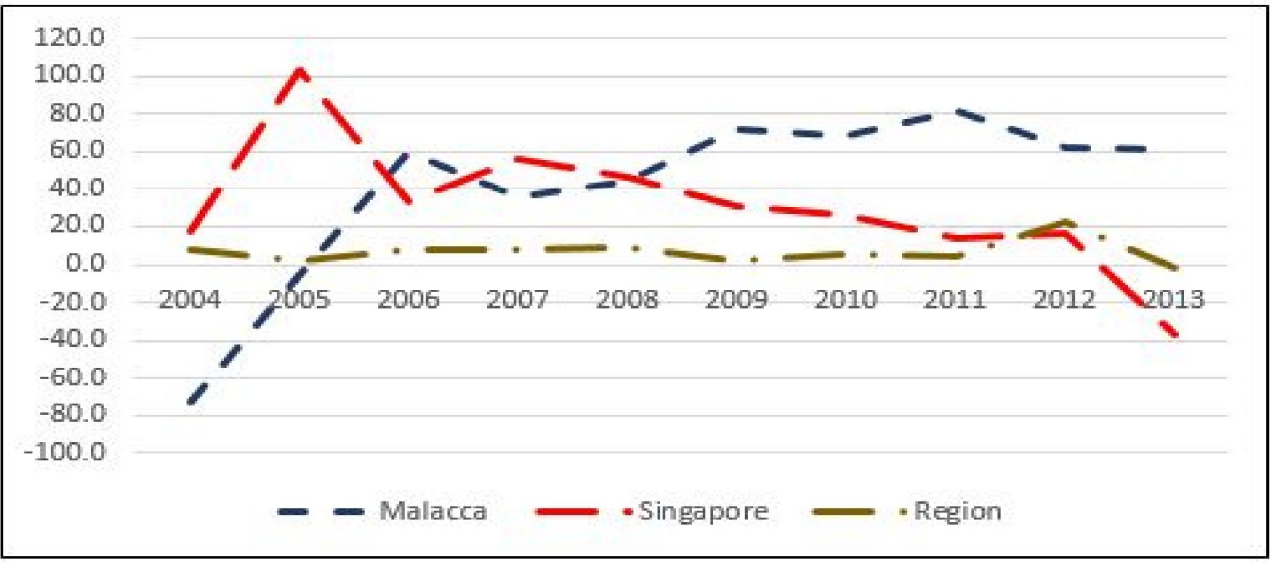

Figure 7.

AMS by zone (Net O-D container throughput)

The results show totally deferent aspects compared with those by OMS, which shows only the stable trend of the market share. One common factor is that Singapore and Malacca show a strong substitutable relation in total and T/S throughput irrespective of the role of Region. The other findings from this analysis are as follows:

First, as in the case of the OMS analysis, the competitiveness of Singapore has been continued either in case of total or T/S throughput. But we can find 3 breakpoints related with the competitive relation between the two, which needs more concrete explanations.

The first period is the point just after the construction of container terminal of PTP. After the construction of PTP, Malacca has gained its competiveness concentrating on the net O-D throughput, though the effect has disappeared after 1 or 2 years.

The second period is the point of global financial crisis. The global financial crisis, and the decrease in international trade has struck a serious shock to Singapore, which is the largest transshipment hub in the world trade, whereas the impact was relatively small in Malacca, which was backed by the net O-D throughput in Malay Peninsula.

The third period is the point that global maritime market was restructured by the 'Big 3' maritime companies in the world. The big 3 companies, armed with larger container ships over 10,000 TEU's and the strategic alliance among them, have started operations of selective calls on the ports with relatively large shipping demands from 2010's. This has resulted in the strengthening of competitiveness of Singapore thereafter.

Second, concentrating on the net O-D throughputs, the competitiveness of Malacca has been getting stronger from 2005. Especially, after the financial crisis, Malacca has taken over the OMS as well as the AMS of Singapore. 
These findings implicate that Malacca has strengthened its role as the regional gateway ports over Singapore, while Singapore maintained or extended its role as the regional transshipment hub port during last 10 years, in spite of several moments of change.

\subsection{AMS Analysis among Ports in Malacca}

The AMS analysis provides some new insights into the competiveness of zones. However, previous studies of competitiveness have focused mainly on port-level analyses. Based on the OMS, the most competitive port in Malacca in 2013 is the Port Klang, followed by PTP, Penang, and Johor. This paper identifies another aspect in port competition by examining AMS by ports; which port leads the trend of AMS in the zone and which port oppose it?

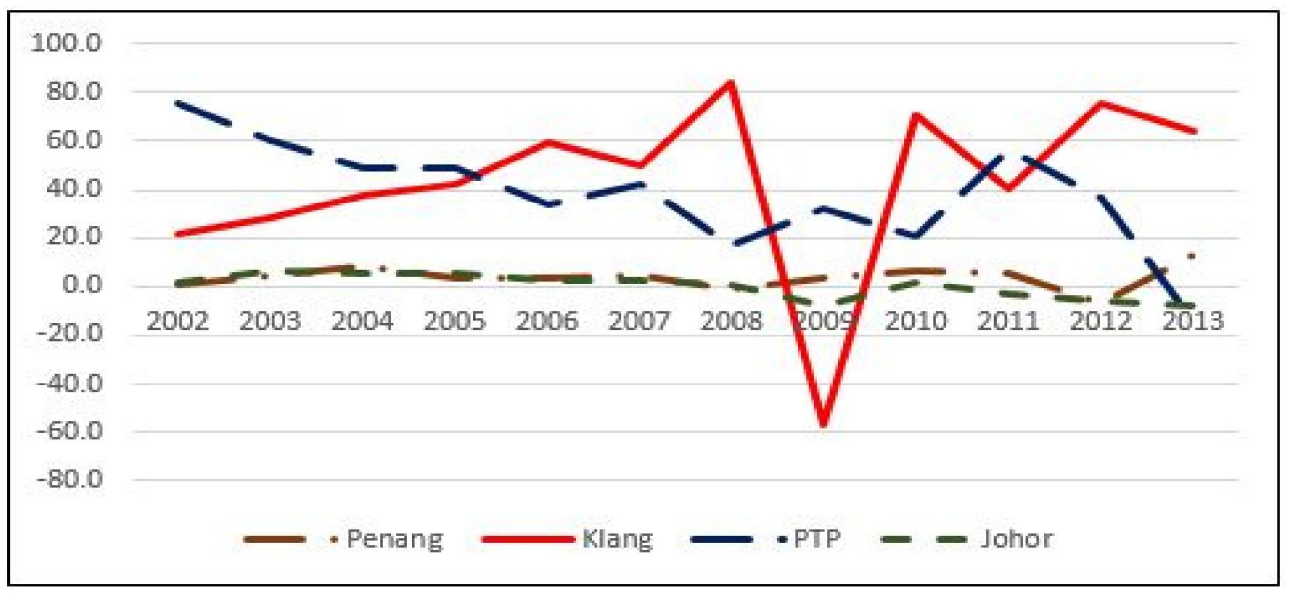

Figure 8.

AMS in Malacca (Total container throughput) 


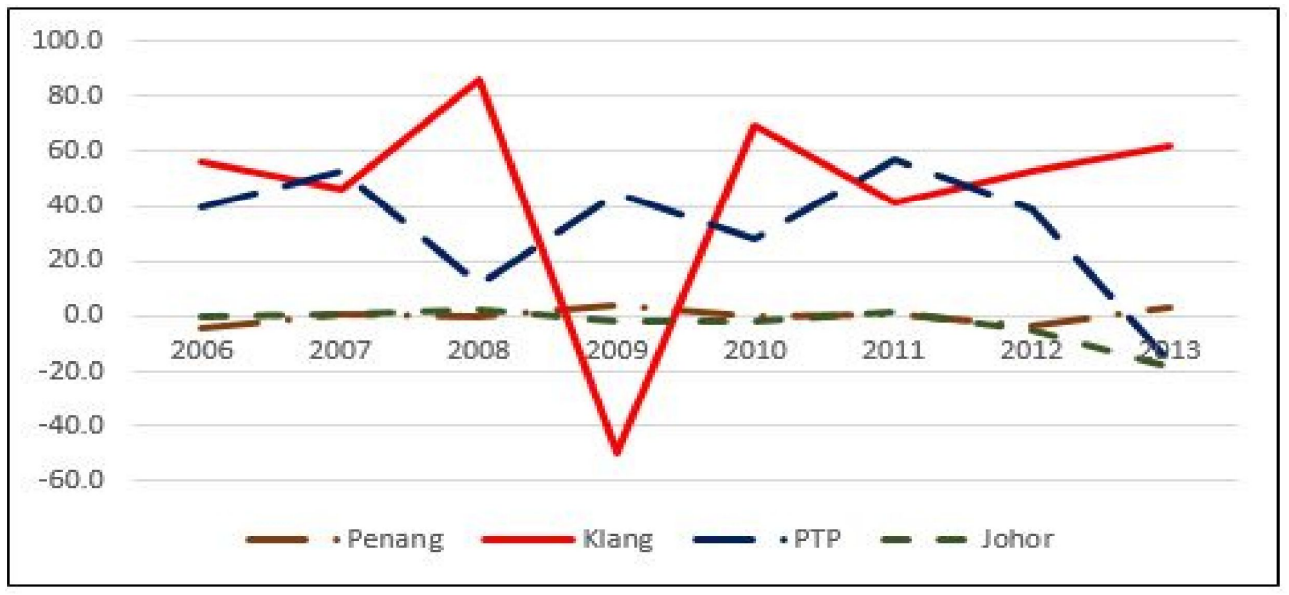

Figure 9.

AMS in Malacca (T/S container throughput)

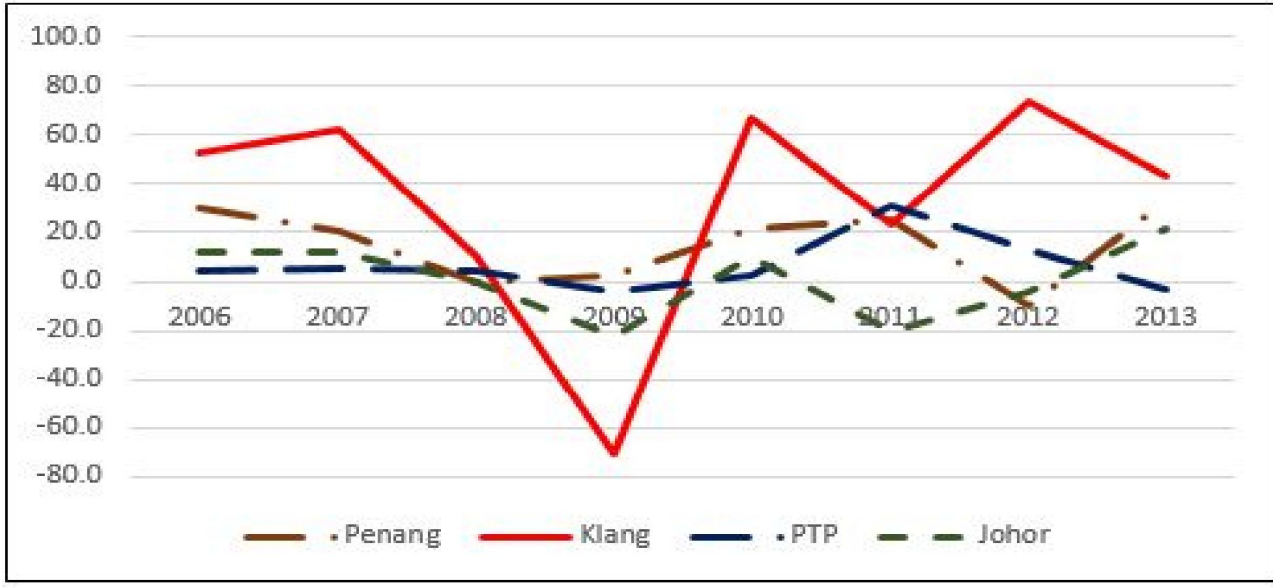

Figure 10.

AMS in Malacca (net O-D container throughput)

Figures 8, 9, and 10 show the AMS trends of container throughput of the major ports in Malacca Strait. As shown in the figures, the overall AMS trend in Port Klang is not different from that of Singapore, and the trend of PTP shows the declining competitiveness except some occasional periods. From this, we can deduce that the function of Port Klang is a kind of regional transshipment hub, though overall function of the ports in Malacca is a regional gateway as concluded in previous sub section. PTP, which locate adjacent to Singapore, does not show the role of transshipment hub, contrary to the expectation on it 
when it was constructed first.

Then, which ports function as the major regional gateway in Malacca? In T/S container throughput, PTP operates slightly as the substitutable port of Port Klang, and, in net O-D throughput, the role of PTP and Penang are distinctive especially from 2011, which is a good contrast with the case of T/S throughput. But the contribution of Port Klang even in net O-D throughput is remarkably high. In summary, Port Klang leads the other ports in the region in terms of the function of regional gateway as well as the regional transshipment hub.

\section{Concluding Remarks}

This paper evaluates the competitiveness of ports in the Malay Peninsula by using a simple but practical method called the AMS. The AMS has the properties of both the OMS and the growth rate and provides insights that cannot be provided by these two measures. If the OMS is a performance indicator based on cumulative changes in external environments, internal capacity, and internal technological advances, among others, then the AMS demonstrates performance by their spot changes. Therefore, following the AMS trend can reveal the overall direction of changes in competitiveness, the time point of any change, and substitutable/complementary relationships between ports based on the direction of responses to a change.

In terms of changes in the competitiveness of Malaysian ports in the 2000s, the major results can be summarized as follows: First, although Malaysian ports especially in Malacca Strait try to grow as the regional transshipment hub during last decade, the competitiveness of Singapore still overpower the other ports concentrating on $\mathrm{T} / \mathrm{S}$ container throughput. But other ports in Malacca Strait has been increasing their role as the regional gateway of net O-D containers. Among the Malaysian ports in Malacca Strait, Port Klang still maintains its role as the regional transshipment hub after Singapore, as well as the regional gateway port. Another issue to attract attentions is that the role of Penang is strengthening, whereas PTP has not shown its potential ability, which was expected at the beginning.

This paper is limited in that it does not identify the reasons behind changes in competitiveness or other results. This is because this paper evaluates "revealed" competitiveness. Despite these limitations, this paper contributes to the literature by proposing a new "revealed" indicator of port performance. The proposed indicator is verified to be more useful than the OMS or others in monitoring changes in the market. 


\section{References}

Balassa, B. (1965), "Trade Liberalization and "Revealed Comparative Advantage," the Manchester School of Economics and Social Studies, 33(2), pp. 99-123.

Cullinane, K., Song, D. W., and Wang, T. F. (2005). The application of mathematical programming approaches to estimating container port production efficiency. Journal of Productivity Analysis, 24(1), pp.73-92.

de Langen, P.W. and Haezendonck, E. (2012), "Ports as Clusters of Economic Activity," in W. K. Talley (Eds.) The Blackwell Companion to Maritime Economics ( $\left(I^{\text {st }} E d\right.$.), pp. 638-655.

de Langen, P.W., Nijdam, M. and van der Horst, M. (2007), "New Indicators to Measure Port Performance," Journal of Maritime Research, 4(1), pp. 23-36.

Kim, G.S. and Kim, T.S. (2010), "Functional Networking of Logistics Port Cities in Northeast Asia," International Journal of Urban Sciences, 14(1), pp.73-85.

Leromain, E. and Orefice, G. (2014), "New Revealed Comparative Advantage Index: Dataset and Empirical Distribution," International Economics, 139(1), pp. 48-70.

Lee, T., Yeo, G. and Thai, V.V. (2014), "Changing Concentration Ratios and Geographical Patterns of Bulk Ports: The Case of the Korean West Coast," the Asian Journal of Shipping and Logistics, 30(2), pp. 155-173.

Liu, C-C. (2008), "Evaluating Operational Efficiency of Major Ports in the Asia-Pacific Region Using Data Envelopment Analysis," Applied Economics, 40(13), pp. 1737-1743.

Liu, N., Gan, H., Zhan, S. and Chen, S. (2013), "Economic and Statistical Analyses of Port Competition within the Shanghai International Shipping Hub," Advances in Information Sciences and Service Sciences, 5(6), pp. 1230-1242.

Low, M.W.J., Lam, S.W. and Tang, L.C. (2009), "Assessment of Hub Status among Asian Ports from a Network Perspective," Transportation Research Part A, 43, pp. 593-606. 
Ng, A. S. F., \& Lee, C. X. (2007). Port productivity analysis by using DEA: A case study in Malaysia. ITLS-WP, 07(11)

Notteboom, T.E. (2009), "Complementarity and Substitutability among Adjacent Gateway Ports," Environment and Planning A, 41, pp.743-762.

Notteboom, T.E. and Rodrigue, J-P. (2005), "Port Regionalization: Towards a New Phase in Port Development," Maritime Policy and Management, 32(3), pp. 297-313.

Pallis, A.A., Vitsounis, T.K. and de Langen, P.W. (2010), "Port Economics, Policy and Management: Review of an Emerging Research Field," Transport Reviews, 30(1), pp.115-161.

Pallis, A.A., Vitsounis, T.K, de Langen, P.W. and Notteboom, T.E. (2011), "Port Economics, Policy and Management: Content Classification and Survey," Transport Reviews, 31(4), pp.445-471.

Talley, W. K. (2004). "Guest editor's foreword," Review of Network Economics, 3(2), pp.83-85.

Talley, W.K. (2007), "Port Performance: An Economics Perspective," in W.K. Talley (Eds.) Research in Transportation Economics (vol.17), pp. 499-516.

Tongzon, J. and Heng, W. (2005), "Port Privatization, Efficiency and Competitiveness: Some Empirical Evidence from Container Ports," Transportation Research Part A, 39, pp. 405-424.

Tsamourgelis, I., Paflioti, P. and Vitsounis, T. (2013), "Seaport Activity (A)synchronicity, Trade Intensity and Business Cycle Convergence: A Panel Data Analysis," International Journal of Maritime, Trade and Economic Issues, 1(1), pp. 67-92.

Why Malaysia. (2010). Developed infrastructure. Retrieved from www.mida.gov.my/en_v2 /index.php

Yeo, G.T., Roe, M. and Dinwoodie, J. (2008), "Evaluating the Competitiveness of Container Ports in Korea and China," Transportation Research Part A, 42, pp. 910-921. 